\title{
Membrane and envelope virus proteins co-expressed as lysosome associated membrane protein (LAMP) fused antigens: a potential tool to develop DNA vaccines against flaviviruses
}

\author{
RAFAEL DHALIA ${ }^{1}$, MILTON MACIEL Jr. ${ }^{2}$, FÁBIA S.P. CRUZ ${ }^{1}$, ISABELLE F.T. VIANA ${ }^{1}$, \\ MARIANA L. PALMA ${ }^{1}$, THOMAS AUGUST ${ }^{2}$ and ERNESTO T.A. MARQUES Jr. ${ }^{1,2,3}$ \\ ${ }^{1}$ Fundação Oswaldo Cruz, Centro de Pesquisas Aggeu Magalhães, Departamento de Virologia \\ Laboratório de Virologia e Terapia Experimental (LaViTE), Av. Professor Moraes Rego s/n \\ Cidade Universitária, Caixa Postal 7472, 50670-420 Recife, PE, Brasil \\ ${ }^{2}$ Johns Hopkins University, School of Medicine, Department of Pharmacology and Molecular Sciences \\ 725 North Wolfe Street, Biophysics Building, Baltimore, Maryland 21205, USA \\ ${ }^{3}$ Johns Hopkins University, School of Medicine, Department of Medicine, Division of Infectious Diseases \\ 725 North Wolfe Street, Biophysics Building, Baltimore, Maryland 21205, USA \\ Manuscript received on August 5, 2008; accepted for publication on March 3, 2009; \\ presented by JERSON L. SILVA
}

\begin{abstract}
Vaccination is the most practical and cost-effective strategy to prevent the majority of the flavivirus infection to which there is an available vaccine. However, vaccines based on attenuated virus can potentially promote collateral side effects and even rare fatal reactions. Given this scenario, the development of alternative vaccination strategies such as DNA-based vaccines encoding specific flavivirus sequences are being considered. Endogenous cytoplasmic antigens, characteristically plasmid DNA-vaccine encoded, are mainly presented to the immune system through Major Histocompatibility Complex class I - MHC I molecules. The MHC I presentation via is mostly associated with a cellular cytotoxic response and often do not elicit a satisfactory humoral response. One of the main strategies to target DNA-encoded antigens to the MHC II compartment is expressing the antigen within the Lysosome-Associated Membrane Protein (LAMP). The flavivirus envelope protein is recognized as the major virus surface protein and the main target for neutralizing antibodies. Different groups have demonstrated that co-expression of flavivirus membrane and envelope proteins in mammalian cells, fused with the carboxyl-terminal of LAMP, is able to induce satisfactory levels of neutralizing antibodies. Here we reviewed the use of the envelope flavivirus protein co-expression strategy as LAMP chimeras with the aim of developing DNA vaccines for dengue, West Nile and yellow fever viruses.
\end{abstract}

Key words: dengue, West Nile, yellow fever, Lysosome-Associated Membrane Protein - LAMP, DNA vaccines.

\section{FLAVIVIRUSES AVAILABLE VACCINES}

The family Flaviviridae is represented by several viruses of medical importance, such as Japanese encephalitis, West Nile, tick-borne encephalitis, yellow fever (Maecker et al. 1998) and dengue (Barrett 2002). Approved human vaccines are available for tick-borne encephalitis, Japanese encephalitis and YF (Barrett 2001),

Correspondence to: Dr. Rafael Dhalia

E-mail: rdhalia@cpqam.fiocruz.br while vaccines for dengue and West Nile remain elusive goals. The main strategy for flavivirus vaccine development has been the attenuation of specific strains, such as the YF 17D and the Japanese encephalitis SA1414-2, or virus inactivation as the tick-borne encephalitis. However, the use of attenuated virus strains can potentially promote harmful effects, such as increased symptom severity and seldom fatal reactions (Liu 2003). In addition, such vaccines are not recommended for in- 
fants less than 9 months old, pregnant women and immunodeficient subjects (Cetron et al. 2002).

The first human flavivirus-attenuated vaccine was the vaccine against YF (17D). In the last 70 years, more than 400 million people worldwide have been vaccinated with the $17 \mathrm{D}$ vaccine with a remarkable record of safety and efficacy (Putnak et al. 2003). The 17D vaccine generates both long-lasting neutralizing antibodies and a $\mathrm{T}$ cell response (Poland et al. 1981, Reinhardt et al. 1998). However, despite several improvements made in the manufacture and quality control process, increased severity of symptoms (Monath et al. 2002) and fatal reactions (Vasconcelos et al. 2001, Lefeuvre et al. 2004) has been systematically associated with the YF virus-attenuated vaccination. Given this scenario, the development of alternative vaccination strategies, such as DNA-based vaccines encoding specific flavivirus sequences, has been considered (Donnelly et al. 1997, Lewis and Babiuk 1999, Robinson 1999, Schultz et al. 2000) and presents some advantages (Table I).

\section{LYSOSOME-ASSOCIATED MEMBRANE PROTEIN (LAMP) TARGET STRATEGY}

Endogenous cytoplasmic antigens, typical of DNA encoded antigens, are mainly presented to the immune system through the Major Histocompatibility Complex (MHC) class I molecules, which are mostly associated with cellular cytotoxic response. However, such responses do not elicit a satisfactory humoral response very often, which is essential for efficient virus neutralization. In fact, the activation of $\mathrm{CD}^{+} \mathrm{T}$ cells is important to support $\mathrm{CD}^{+} \mathrm{T}$ cell responses and the development of memory, antibody class switching and clonal expansion of antigen-specific B cells (Rocha and Tanchot 2004). The activation of $\mathrm{CD}^{+} \mathrm{T}$ cells requires the Antigen-Presenting Cells (APCs) with antigenic peptides loaded into the groove of MHC class II molecules. The loading of the antigenic peptide takes place in intracellular organelles rich in $\mathrm{MCH}$ class II molecules, termed MIIC (Kleijmeer et al. 1997, Drake et al. 1999).

Lysosome-associated membrane protein (LAMP) molecules, which are naturally found in the outer membrane of lysosomes (Lippincott-Schwartz and Fambrough 1986), traffic through the MIIC and the in-frame expression of antigens within LAMP, in plasmid DNA constructs, is able to drive the new translated chimerical antigen into the MIIC. LAMP/antigen chimeras, like LAMP/HIV Gag (Marques et al. 2003, Chikhlikar et al. 2004, Arruda et al. 2004, 2006) and LAMP/dengue virus 2 (Raviprakash et al. 2000, Lu et al. 2003), have been shown to target the antigens to MIIC and were found to elicit enhanced immune responses when compared to DNA vaccines encoding unmodified native antigens.

Considering that the flavivirus envelope (E) protein is recognized as the major virus surface protein and the main target for neutralizing antibodies, this antigen constitutes a potential target for DNA vaccines development initiatives. The targeting of flavivirus $\mathrm{E}$ protein to the MIIC has been shown to enhance neutralizing antibody (Turley et al. 2000) production in immunized mice (Raviprakash et al. 2001, Donnelly et al. 2003, Anwar et al. 2005) and in non-human primates (Dr. Kanakatte Raviprakash, personal communication).

\section{DEVELOPMENT OF DNA-BASED VACCINES AGAINST FLAVIVIRUSES: MEMBRANE-ENVELOPE PROTEINS CO-EXPRESSED AS LAMP FUSED ANTIGENS}

The genome of the yellow fever virus, the prototype of the flavivirus family, is organized in a single-stranded positive-sense RNA molecule of $\sim 10.8 \mathrm{~Kb}$, flanked by a 5' cap and a 3 ' non-polyadenylated terminal loop structure. It encodes three genes for structural proteins (Capsid, Membrane - M, and E) and seven genes for nonstructural (NS) proteins (NS1, NS2a, NS2b, NS3, NS4a, $\mathrm{NS} 4 \mathrm{~b}$, and NS5). Co-expression of flavivirus $\mathrm{M}$ and $\mathrm{E}$ genes in mammalian cells has shown to produce VirusLike Particles (VLPs) containing M and E proteins (Raviprakash et al. 2000, Lu et al. 2003, Wu et al. 2006). The VLP structure preserves viral conformational epitopes that are responsible to induce B-cells neutralizing antibodies production and, as a consequence, virus infection neutralization (Wu et al. 2006).

Different groups previously described the development of flavivirus DNA vaccines based on the expression of different viruses' $M$ and $E$ regions as wild type proteins, as well as chimerical proteins associated to LAMP. The $\mathrm{M}$ and $\mathrm{E}$ flavivirus proteins co-expressed as LAMP fused antigens, delivered as DNA vaccines, seems to be a promising approach to prevent flavivirus infections. Our research group is currently using this technology aim- 
TABLE I

Comparison between virus-attenuated and wild type and LAMP fused DNA-based vaccines.

\begin{tabular}{|c|c|c|c|}
\hline & Attenuated-virus vaccines & DNA-based vaccines & LAMP-targeted DNA vaccines \\
\hline Humoral response & +++ & + & ++ \\
\hline CD4 response & +++ & + & +++ \\
\hline CD8 response & +++ & +++ & +++ \\
\hline Safety & $\begin{array}{l}\text { Risk depends on the subject, } \\
\text { age and health status }\end{array}$ & \multicolumn{2}{|c|}{$\begin{array}{c}\text { (?) } \\
\text { Experiments with rodents and non-human primate trials did } \\
\text { not show significant side effects }\end{array}$} \\
\hline Human use & ++ & $\begin{array}{l}\text { (?) } \\
\text { No vaccine approved to } \\
\text { this date; three veterinary } \\
\text { vaccines approved }\end{array}$ & $\begin{array}{l}(?) \\
\text { No vaccine approved to } \\
\text { this date }\end{array}$ \\
\hline Development & $\begin{array}{l}+ \\
\text { The development of new } \\
\text { attenuated strains is time } \\
\text { consuming and greatly based } \\
\text { on guesswork }\end{array}$ & $\begin{array}{l}\text { Can be tailored-developed } \\
\text { through DNA recombinant } \\
\text { methods, incorporating desired } \\
\text { signals to better activate the } \\
\text { immune system }\end{array}$ & $\begin{array}{l}\text { Allows the chimerical } \\
\text { expression of whole proteins } \\
\text { or only T cell epitopes }\end{array}$ \\
\hline Evaluation/testing & $\begin{array}{l}\text { Due to the presence of an alive } \\
\text { organism, final evaluation in } \\
\text { specific hosts is usually } \\
\text { required due to the virus tropism }\end{array}$ & \multicolumn{2}{|c|}{$\begin{array}{l}+++ \\
\text { s, rodents and non-human primates } \\
\text { can be used }\end{array}$} \\
\hline Adjuvancy & $\begin{array}{c}++ \\
\text { Usually, the alive virus } \\
\text { activates the immune system } \\
\text { through its own adjuvant } \\
\text { properties }\end{array}$ & $\begin{array}{c}\text { ++ } \\
\text { Potentially, DNA allows for } \\
\text { the manipulation of the } \\
\text { immune response in many } \\
\text { different ways; it can be used } \\
\text { in combination with } \\
\text { cytokines and/or delivery systems } \\
\text { the presence of CpG motifs } \\
\text { in the DNA backbone works } \\
\text { as a TOLL activator }\end{array}$ & $\begin{array}{l}\text { ++ } \\
\text { LAMP works as a } \\
\text { "molecular adjuvant"; it can } \\
\text { be combined with cytokines } \\
\text { and delivery systems; } \\
\text { the presence of CpG motifs } \\
\text { in the DNA backbone works } \\
\text { as a TOLL activator }\end{array}$ \\
\hline Mass production & $\begin{array}{c}\text { Labor intensive and usually } \\
\text { dependent on cell culture or } \\
\text { embryonated eggs; the production } \\
\text { system can lead to the presence } \\
\text { of impurities and undesirable } \\
\text { components that can lead to allergy }\end{array}$ & \multicolumn{2}{|c|}{$\begin{array}{c}\text { Can be produced without the use of animal products } \\
\text { and easily purified }\end{array}$} \\
\hline $\begin{array}{l}\text { Transportation/ } \\
\text { distribution }\end{array}$ & $\begin{array}{l}\text { Usually requires a cold chain } \\
\text { for distribution }\end{array}$ & \multicolumn{2}{|c|}{$\begin{array}{l}\text { Easy to transport and preserve, and it is stable } \\
\text { at room-temperature }\end{array}$} \\
\hline
\end{tabular}

ing to develop DNA vaccines against West Nile, dengue and yellow fever viruses. All wild type DNA constructs comprise a region extending from the capsid reticulum endoplasmic (ER) translocation signal to the E protein transmembrane domain. In parallel, the fused LAMP constructs were obtained through the replacement of $\mathrm{E}$ protein transmembrane domain by the C-terminal do- main of LAMP (Fig. 1). Despite the substitution of the $\mathrm{E}$ protein transmembrane domain by LAMP, M-ELAMP constructs also seem to be able to generate VLPs (Raviprakash et al. 2001).

Raviprakash and co-workers (2001) first evaluated $\mathrm{M}$ and $\mathrm{E}$ co-expression strategy as wild type and LAMPfused proteins, in terms of localization and immuno- 


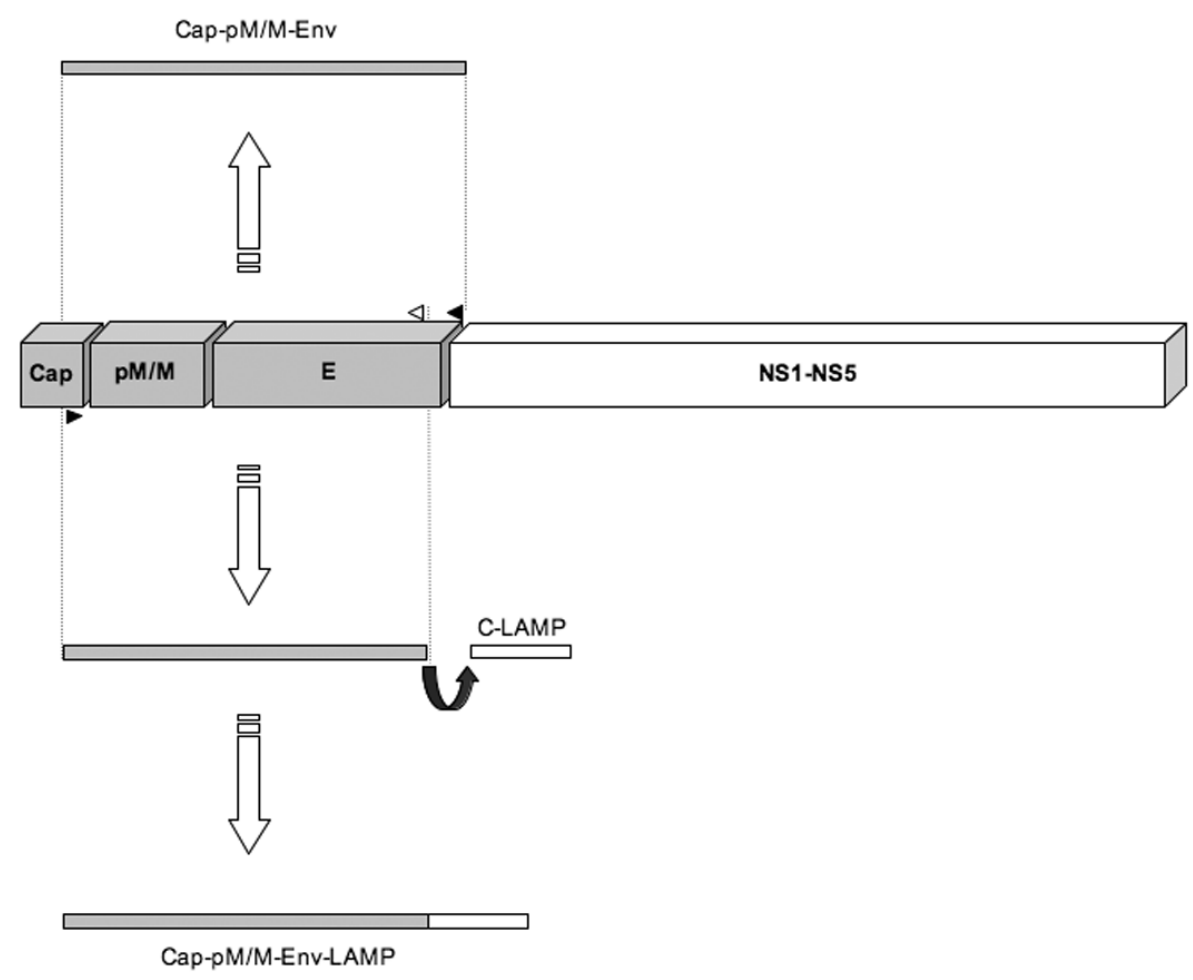

Fig. 1 - Membrane-Envelope flavivirus DNA vaccine constructs: co-expression as wild type and as LAMP fused antigens. Polymerase Chain Reaction - PCR amplification was performed to obtain Membrane (M) and Envelope (E) co-expressed flavivirus-based DNA vaccines. To generate the M-E wild type constructs, specific primers were designed to amplify a fragment extending from the capsid reticulum endoplasmic (ER) translocation signal to the E protein transmembrane domain (cap-pM/M-Env or M-E). To generate the M-E/LAMP fused constructs, specific reverse primers were designed to annealed just before the envelope transmembrane domain to allow its substitution by the Carboxi-terminal domain of the Lysosome Associated Membrane Protein - LAMP (Cap-pM/M-Env-LAMP or M-E/LAMP).

genicity, by using dengue virus type 2 as a model. Expression and cellular steady-state localization of the dengue virus antigens were compared to those of the cellular endogenous LAMP by dual fluorescence staining and confocal microscopy. These imaging studies showed the co-localization of the dengue virus proteins in LAMP-containing organelles in DNA-transfected NIH3T3 cells. In in vivo experiments, M-E and M-E/LAMP encoded DNA plasmids were used in mouse immunization protocols. No mice immunized with ME DNA seroconverted, while all mice immunized with M-E/LAMP DNA seroconverted on day 30, presenting Plaque-Reduction Neutralization Test - PRTN $_{50}$ titers of 49 to 270 .

$\mathrm{Lu}$ and co-workers (2003) continued the studies on $\mathrm{M}$ and $\mathrm{E}$ co-expression to evaluate the memory response. First, the authors evaluated the expression of both dengue proteins by Western blot analysis, confirming the expected specific bands corresponding to the glycosylated and processed protein forms of both the native $\mathrm{E}$ and the E/LAMP chimera. The lysosomal-like distribution of M-E/LAMP and the co-localization of MHC II and LAMP molecules were also confirmed through fluorescence and confocal microscopy. To evaluate the immunogenicity of their vaccines, M-E and M-E/LAMP encoded DNA constructs, the immune responses of the immunized mice were followed for 1 year. Both DNA constructs were used for mice immunization and the antibody response was measured by Enzyme Linked Immuno Sorbent Assay - ELISA. None of the serum samples of the M-E DNA immunized group showed a significant titer of virus neutralization, while sera of the ME/LAMP DNA immunized group showed strong virus neutralization capability. 
Anwar and co-workers (2005) used the M-E/LAMP strategy to develop a West Nile (WN) DNA vaccine. Their Western blot findings showed an increased intracellular concentration of the M-E/LAMP chimerical protein in transfected cells when compared to the native protein. This result pointed to a natural cellular secretion of $\mathrm{E}$ protein that may be retarded by the association between the LAMP signal and the outer membrane of the lysosome. The confocal and immunoelectron microscopy analyses showed the typical lysosomal distribution of the WN M-E/LAMP and the co-localization with endogenous LAMP, MHC class II, and H-2M molecules, the latter of which is closely related to antigen presentation. To evaluate the immunogenicity of the

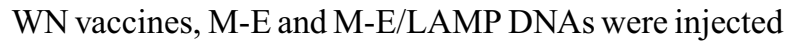
in mice that were followed for 2 years after the immunization. Mice immunized with M-E showed appreciable endpoint titers, but their antibody responses were not sustained after 3 months. In contrast, mice immunized with M-E/LAMP showed high antibody responses, with increasing titers from days 55 to 125 , and a significant neutralization titer response at days 90 and 125 . To assess the presence of memory $B$ cell response, the mice were boosted 19 months after the last immunization, and the blood collected 2 weeks later. While there was no significant neutralization activity in the sera from the ME DNA immunized group, the sera from the M-E/LAMP DNA immunized group showed significant neutralization titers.

We are currently evaluating a DNA construct expressing the envelope of the YF, fused to LAMP molecules, in murine immunization experiments. Immunizations with YF M-E/LAMP encoded DNA showed high titers of neutralizing antibodies that were able to protect the animals from the intracerebral challenge with the YF virus. In addition, when compared to the attenuated 17DD YF virus vaccine, the plasmid DNA expression of the E protein within LAMP induced similar $\mathrm{CD}^{+}$and $\mathrm{CD}^{+} \mathrm{T}$ cell responses, qualitatively and quantitatively (data not shown).

\section{FUTURE DIRECTIONS}

In order to improve the DNA-codified antigen expression in human cells, we are currently developing codonoptimized vaccines by using a genetic algorithm (LETO
1.0 - Entelechon $\left.{ }^{\circledR}\right)$. Parameters as codon usage, message RNA secondary structures, cryptic splice sites, and internal restriction sites, among others, have been modified and/or removed from the native sequences. The blend of LAMP fusion and codon optimization technologies shows promising potential and may lead to new and better DNA vaccines. Our preliminary evaluations of the novel YF optimized DNA vaccine constructs address the levels and localization of the protein expression. By immunofluorescence assays, the translation efficiency of the optimized vaccines was considered at least 20 times higher (data not shown). Considering the higher efficiency of the optimized M-E/LAMP DNA constructs (M-E $\left.\mathrm{E}_{\mathrm{OPT}} / \mathrm{LAMP}\right)$, compared to the nonoptimized version, we believe that the optimized version will be able to induce much stronger $\mathrm{T}$ and $\mathrm{B}$ cell responses in animal models. Ultimately, the improvement of the level of antigen expression will allow us to reduce the number and concentration of the DNA vaccine dose used in in vivo immunization experiments.

\section{ACKNOWLEDGMENTS}

The authors are in debt with Miss Meagan Fitzpatrick and Mrs. Claudia Costabile for the helpful editorial review of the manuscript.

\section{RESUMO}

A vacinação é a estratégia mais prática e o melhor custo-benefício para prevenir a maioria das infecções dos flavivírus, para os quais existe vacina disponível. Entretanto, as vacinas baseadas em vírus atenuados podem potencialmente promover efeitos colaterais e, mais raramente, reações fatais. Diante deste cenário, o desenvolvimento de estratégias alternativas de vacinação, como vacinas baseadas em DNA codificando seqüências específicas dos flavivírus, está sendo considerado. Antígenos citoplasmáticos endógenos, caracteristicamente codificados por vacinas de DNA plasmidial, são majoritariamente apresentados ao sistema imune através de moléculas do Complexo Maior de Histocompatibilidade de classe I - MHC I. A via de apresentação MHC I é mais associada à resposta celular citotóxica e, frequentemente, não elicita uma resposta humoral satisfatória. Uma das principais estratégias para direcionar antígenos codificados pelas vacinas de DNA para o compartimento MHC II é expressar estes antígenos dentro 
da Proteína de Associação à Membrana Lisossomal (LAMP). A proteína do envelope dos flavivírus é reconhecidamente a principal proteína de superfície viral e o principal alvo para anticorpos neutralizantes. Diferentes grupos têm demonstrado que a co-expressão das proteínas de membrana e do envelope dos flavivírus em células de mamíferos, fusionada com a porção carboxi-terminal de LAMP, é capaz de induzir níveis satisfatórios de anticorpos neutralizantes. Neste trabalho revisamos a estratégia de co-expressão da proteína do envelope dos flavivírus, como quimeras de LAMP, com o objetivo de desenvolver vacinas de DNA contra a febre do Oeste do Nilo, dengue e febre amarela.

Palavras-chave: dengue, febre do Oeste do Nilo, febre amarela, Proteína de Associação à Membrana Lisossomal - LAMP, vacinas de DNA.

\section{REFERENCES}

AnWAR A ET AL. 2005. West Nile premembrane-envelope genetic vaccine encoded as a chimera containing the transmembrane and cytoplasmic domains of a lysosome-associated membrane protein: increased cellular concentration of the transgene product, targeting to the MHC II compartment, and enhanced neutralizing antibody response. Virology 332: 66-77.

ARRUDA LB ET AL. 2004. DNA vaccine encoding human immunodeficiency virus-1 Gag, targeted to the major histocompatibility complex II compartment by lysosomalassociated membrane protein, elicits enhanced long-term memory response. Immunology 112: 126-133.

Arruda LB ET AL. 2006. Dendritic cell-lysosomal-associated membrane protein (LAMP) and LAMP-1-HIV-1 gag chimeras have distinct cellular trafficking pathways and prime $\mathrm{T}$ and $\mathrm{B}$ cell responses to a diverse repertoire of epitopes. J Immunol 177: 2265-2275.

BARRETT AD. 2001. Current status of flavivirus vaccines. Ann N Y Acad Sci 951: 262-271.

Barrett AD. 2002. Arilvax (PowderJect). Curr Opin Investig Drugs 3: 992-995.

Cetron MS ET AL. 2002. Yellow fever vaccine. Recommendations of the Advisory Committee on Immunization Practices (ACIP), 2002. MMWR Recomm Rep 51 (RR17): 1-11.

Chikhlikar P ET AL. 2004. Inverted terminal repeat sequences of adeno-associated virus enhance the antibody and $\mathrm{CD} 8(+)$ responses to a HIV-1 p55Gag/LAMP DNA vaccine chimera. Virology 323: 220-232.
DonNelly JJ ET AL. 1997. DNA vaccines. Annu Rev Immunol 15: 617-648.

DONNELLY JJ ET AL. 2003. Technical and regulatory hurdles for DNA vaccines. Int J Parasitol 33: 457-467.

DRAKE JR ET AL. 1999. Involvement of MIIC-like late endosomes in $\mathrm{B}$ cell receptor-mediated antigen processing in murine B cells. J Immunol 162: 1150-1155.

KLEIJMEER MJ ET AL. 1997. Major histocompatibility complex class II compartments in human and mouse B lymphoblasts represent conventional endocytic compartments. J Cell Biol 139: 639-649.

Lefeuvre A et AL. 2004. Current Assessment of Yellow Fever and Yellow Fever Vaccine. Curr Infect Dis Rep 6: 96-104.

LEWIS PJ AND BABIUK LA. 1999. DNA vaccines: a review. Adv Virus Res 54: 129-188.

LipPincotT-SCHWARTZ J AND FAMBROUGH DM. 1986. Lysosomal membrane dynamics: structure and interorganellar movement of a major lysosomal membrane glycoprotein. J Cell Biol 102: 1593-1605.

LIU MA. 2003. DNA vaccines: a review. J Intern Med 253: $402-410$

LU Y ET AL. 2003. Dengue 2 PreM-E/LAMP chimera targeted to the MHC class II compartment elicits long-lasting neutralizing antibodies. Vaccine 21: 2178-2189.

MAECKer HT ET AL. 1998. Cytotoxic T cell responses to DNA vaccination: dependence on antigen presentation via class II MHC. J Immunol 161: 6532-6536.

MARQUES ETA JR. ET AL. 2003. HIV-1 p55Gag encoded in the lysosome-associated membrane protein-1 as a DNA plasmid vaccine chimera is highly expressed, traffics to the major histocompatibility class II compartment, and elicits enhanced immune responses. J Biol Chem 278: 37926-37936.

Monath TP ET AL. 2002. Single mutation in the flavivirus envelope protein hinge region increases neurovirulence for mice and monkeys but decreases viscerotropism for monkeys: relevance to development and safety testing of live, attenuated vaccines. J Virol 76: 1932-1943.

POLAND JD ET AL. 1981. Persistence of neutralizing antibody 30-35 years after immunization with 17D yellow fever vaccine. Bull World Health Organ 59: 895-900.

PutNAK R ET AL. 2003. DNA vaccines for flaviviruses. Adv Virus Res 61: 445-468.

RAVIPRAKASH K ET AL. 2000. Immunogenicity of dengue virus type 1 DNA vaccines expressing truncated and full length envelope protein. Vaccine 18: 2426-2434. 
RAVIPRAKASH K ET AL. 2001. Synergistic neutralizing antibody response to a dengue virus type 2 DNA vaccine by incorporation of lysosome-associated membrane protein sequences and use of plasmid expressing GM-CSF. Virology 290: 74-82.

REINHARDT B ET AL. 1998. Development of viremia and humoral and cellular parameters of immune activation after vaccination with yellow fever virus strain 17D: a model of human flavivirus infection. J Med Virol 56: 159-167.

ROBINSON HL. 1999. DNA vaccines: basic mechanism and immune responses (Review). Int J Mol Med 4: 549-555.

ROCHA B AND TANCHOT C. 2004. Towards a cellular definition of CD8+ T-cell memory: the role of CD4+ T-cell help in CD8+ T-cell responses. Curr Opin Immunol 16: 259-263.
SCHULTZ J ET AL. 2000. Immune modulation in cancer using DNA inoculation-antitumour effect of interleukin12. Dev Biol (Basel) 104: 109-114.

TURLEY SJ ET AL. 2000. Transport of peptide-MHC class II complexes in developing dendritic cells. Science 288 (5465): 522-527.

VASCONCELOS PF ET AL. 2001. Serious adverse events associated with yellow fever 17DD vaccine in Brazil: a report of two cases. Lancet 358 (9276): 91-97.

WU CJ ET AL. 2006. Development of an effective Japanese encephalitis virus-specific DNA vaccine. Microbes Infect 8: $2578-2586$. 